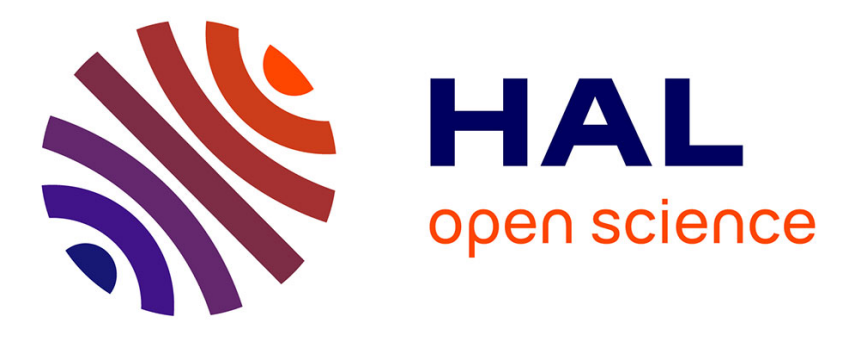

\title{
Introduction: A bird's-eye view of lexical blending
}

\author{
Vincent Renner, François Maniez, Pierre J. L. Arnaud
}

\section{To cite this version:}

Vincent Renner, François Maniez, Pierre J. L. Arnaud. Introduction: A bird's-eye view of lexical blending. Vincent Renner; François Maniez; Pierre Arnaud. Cross-Disciplinary Perspectives on Lexical Blending, De Gruyter Mouton, pp.1-9, 2012, Trends in Linguistics - Studies and Monographs, 978-3-11-028923-7. hal-00799934

\section{HAL Id: hal-00799934 https://hal.science/hal-00799934}

Submitted on 13 Mar 2013

HAL is a multi-disciplinary open access archive for the deposit and dissemination of scientific research documents, whether they are published or not. The documents may come from teaching and research institutions in France or abroad, or from public or private research centers.
L'archive ouverte pluridisciplinaire HAL, est destinée au dépôt et à la diffusion de documents scientifiques de niveau recherche, publiés ou non, émanant des établissements d'enseignement et de recherche français ou étrangers, des laboratoires publics ou privés. 


\title{
Introduction: A bird's-eye view of lexical blending
}

\author{
Vincent Renner, François Maniez, and Pierre J.L. \\ Arnaud
}

\section{A brief retrospective view}

Lexical blends have been popularized in English by the Victorian author Lewis Carroll, who not only elaborated many new formations made up of word fragments, but also pondered on the process of lexical blending in his writings:

\begin{abstract}
Well, "slithy" means "lithe and slimy." "Lithe" is the same as "active." You see, it's like a portmanteau - there are two meanings packed up into one word.
\end{abstract}

Alice's Adventures in Wonderland (1865).

For instance, take the two words "fuming" and "furious." Make up your mind that you will say both words, but leave it unsettled which you will say first. Now open your mouth and speak. If your thoughts incline ever so little towards "fuming," you will say "fuming-furious;" if they turn, by even a hair's breadth, towards "furious," you will say "furious-fuming;" but if you have the rarest of gifts, a perfectly balanced mind, you will say "frumious."

Preface to The Hunting of the Snark (1876).

Blends, however, long predate the latter half of the nineteenth century. Early examples which have survived until the present day include, for instance, Middle French écornifler 'to nose about and steal' $(<$ écorner 'to cut off' + nifler 'to sniff'), Early Modern English foolosopher $(<$ fool + philosopher) and Middle Polish pstrokaty 'motley' (< pstry 'multicolored' + srokaty 'piebald').

Lexical blending is attested in a variety of typologically different languages - e.g. French (Fradin, Montermini, and Plénat 2009), Hebrew (Berman 1989), Indonesian (Dardjowidjojo 1979), Mandarin Chinese (Ronneberger-Sibold, this volume) -, but much of the specialized literature has dealt with English, both because it is assuredly the most researched 
language of modern times, and also because of the relative productivity of the process in Late Modern English. English blends notably multiplied in the course of the twentieth century (Ayto 2003), which concurrently led to an increasing number of scholarly works investigating the phenomenon, among which one can mention the widely quoted articles by John Algeo, Blends, a Structural and Systemic View (1977), and by Garland Cannon, Blends in English word formation (1986). Several influential papers - Kubozono (1990), Bat-El (1996), Lehrer (1996) and Kelly (1998) - appeared in the 1990s and undoubtedly gave a new impetus to research in the field, providing fresh insights from a phonological and psycholinguistic perspective. This has resulted in a wide-ranging body of research spanning several linguistic fields - from phonology (e.g. Cutler and Young 1994) to psycholinguistics (e.g. Lehrer 2003), to cognitive (e.g. Kemmer 2003; Gries 2006) and computational (e.g. Cook and Stevenson 2010; Veale and Butnariu 2010) linguistics -, frameworks, notably Optimality Theory (e.g. Piñeros 2004; Hong 2005), and languages (e.g. Bertinetto 2001; Brdar-Szabó and Brdar 2008).

\section{Terminological and definitional dissonance}

The term lexical blend has nowadays mostly displaced Carroll's portmanteau (word), which is however still used either as an occasional synonym for lexical blend (e.g. Veale and Butnariu 2010; Konieczna, this volume) or to refer to a subcategory of blends (e.g. Algeo 1977; Piñeros 2004; Trommer and Zimmermann, this volume). The words which give the fragments from which a blend is built are usually termed source words; less frequent synonyms include base word (e.g. Bat-El and Cohen, this volume), constituent (word) (e.g. Kelly 1998; Konieczna, this volume; Ralli and Xydopoulos, this volume) and etymon (e.g. Cannon 2000). The constitutive fragments of a blend are commonly designated as splinters (e.g. López Rúa, this volume; Ronneberger-Sibold, this volume). Splinter may also refer to bound morphemes such as Franken- (from Frankenstein) and -nomics (from economics), which originated in blend formations (Bauer 2004); this has led to the use of the term fracto-lexeme to refer to word fragments which do not have morphemic status (Renner and Lalić-Krstin 2011). Authors who do not consider that complex words made up of two initial submorphemic splinters (e.g. napalm $<$ naphthenate + palmitate) should be labelled blends use the term complex clipping (e.g. Gries, this 
volume), clipped compound (e.g. Bat-El and Cohen, this volume) or clipping compound (e.g. Bauer, this volume).

Linguists have never quite agreed on the exact delimitation of the concept of lexical blending, and the contributors to the present volume are no exception. Some authors consider that the clipping of one source word is enough to qualify for membership in the category (e.g. Lehrer 2007; BrdarSzabó and Brdar 2008; Konieczna, this volume; López Rúa, this volume), but others exclude various types of complex words, as the following sample of criteria present in the literature shows:

- For Bat-El (2006: 66) and Bauer (this volume), a complex word is unambiguously a blend only in case of truncation at the "inner edges", i.e. if the left source word has been back-clipped and the right source word foreclipped.

- For Ralli and Xydopoulos (this volume), a complex word is a blend only if no source word remains intact and they exclude words of the slanguage $(<$ slang + language) type, when $n$ final segments of the left source word overlap with $n$ initial segments of the right source word.

- For Dressler (2000), complex words whose source words are not in a semantically coordinate relation (i.e. are in a modifier-head relation), such as motel ( $<$ motor + hotel), are excluded from the category; for Plag (2003: $123)$, "proper blends" are those which semantically "resemble copulative compounds", i.e. are coordinate.

- For Arcodia and Montermini (this volume), complex words which do not manifest overlapping of part of their source words are excluded and categorized as reduced compounds.

- For Tomaszewicz (this volume), if there are no output-to-output correspondence relations at the level of metrical structure between the source words and the resulting complex word, the complex word is not, strictly speaking, a blend.

In order to accommodate the many diverging views, one may resort to adopting a prototypical approach and consider that the most inclusive definition is the one to be retained and that the above characteristics are not to be taken as defining features, but as typicality features. The corollary of a prototypical approach is the existence of fuzzy boundaries, which is not in itself a problem for descriptivists - López Rúa (2004) for instance shows how such an approach can work -, but Bauer (this volume) underlines that the uncertain limits of the phenomenon may be an obstacle in the quest for the elusive singularity of blends. 


\section{Outline of the volume}

This collection of articles has its origin in a conference on lexical blending which was organized at the University of Lyon in June 2010. The aim of the conference was to bring together linguists working in various languages and different disciplines or frameworks in order to encourage debate and cross-fertilization of ideas. Eleven papers from the conference, together with one invited contribution, make up the contents of the volume, whose goal is to combine perspectives in order to give a broad overview of the current research and act as a catalyst for further cross-linguistic and crossdisciplinary investigation. The subject is approached from a variety of disciplinary vantage points (morphological, semantic, phonological, cognitive), methodological approaches (experimental, statistical, corpus-based, contrastive) and theoretical frameworks (Combinatory Logic, formal semantics, Natural Morphology, Optimality Theory and its Output-to-Output Correspondence Theory and Coloured Containment versions).

A first group of seven articles provides theoretically informed descriptions of salient aspects of lexical blending in a variety of understudied and typologically diverse languages (the Germanic, Slavic, Greek, Iranian and Chinese subfamilies are represented). In the introductory chapter, Laurie Bauer underlines that lexical blending is best grasped if it is understood as a prototypical category whose description centers around a number of defeasible constraints. He examines a series of constraints which are thought to influence the output form of a blend, discusses the semantics of coordinate blends, and concludes by making a plea for a firmer delineation of the category, stressing that these formations have not been accounted for in an entirely satisfactory way yet and that further investigation and a "flash of insight" are still needed to adequately capture the essence of lexical blending.

In Beyond all reasonable transgression: lexical blending in alternative music, Paula López Rúa approaches the issue of blend formation by analyzing a corpus of blends naming bands and singers in the field of alternative music, from the point of view of form, underlying structure and purpose. Her corpus reveals a high frequency of items formed out of two bases and of combinations which retain the left source word or even both source words in their entirety. She also observes a tendency towards high constituent integration, and the occasional presence of an underlying grammatical modification relationship and of what she calls "transgressive semantic combinations". She concludes that while lexical blending is primarily used 
to catch the audience's attention, it also conveys information about the artists' views on life, society or their art and thus represents the subculture to which they belong, reinforcing group bonds.

In the third chapter, Angela Ralli and George Xydopoulos examine blending in Modern Greek, which constitutes a recent phenomenon and is still limited to slang and some dialects. They make a case for blends being structurally similar to the stem-word compounds of Greek, with differences being the absence of a linking element and form reduction predominantly on the nonhead. Like compounds, blends must combine the denotations of their constituents and the authors show that some recent jocular formations are purely formal and their lack of meaning disqualifies them as blends. Beyond the discussion of the morphological creativity involved in blends vs. compounds, the descriptive side of the paper shows how blending appears in a language that did not have it before.

In Lexical blending in Polish: a result of the internationalization of Slavic languages, Ewa Konieczna echoes Ralli and Xydopoulos by explaining that lexical blending in Polish had been extremely rare until English started penetrating the Slavic languages, first in the 1960s, and then, more visibly, once the Cold War ended. She collected 234 blends from present-day Polish (a majority of which are nonce-formations) and her study details their main formal and semantic characteristics. Especially worthy of note is the fact that, in Polish, overlapping of part of the source words significantly correlates with pejorative connotation, and also the fact that graphic blends, i.e. blends which can only be identified through graphic means (e.g. przeNIKanie < przenikanie + NIK) form a sizable formal subtype.

Investigating lexical blending in another Slavic language, Susanne R. Borgwaldt, Tetyana Kulish and Arpita Bose analyze the structural characteristics of Ukrainian spoken blends that were produced in a hybridobject naming task. Whereas previous research has mostly dealt with deliberate word-formation (written blends) or unintentional speech errors (spoken blends), their corpus consists of spoken blends that were intentionally coined in an experiment for which they used digitally manipulated color photographs of hybrid objects and asked native Ukrainian speakers to give them a name. After a brief explanation of the principles of word-formation in Ukrainian, they present the results of their hybrid-object naming study, focusing on the structure of blends and other subtractive word-formations in their data, and use their corpus to test prevalent theories of preferred blend structures. 
Giorgio Francesco Arcodia and Fabio Montermini's article first looks at Russian "stump compounds" like filfak 'phil(ological) fac(ulty)', and views them as resulting from a combination of constraints, such as the need for each element to correspond to the minimal word pattern and also the need for the first element to be identifiable. They appeal to the Cognitive linguistics concept of conventionalization to conclude that, due to their highly constrained properties, Russian stump compounds are close to "canonical compounds". The authors then turn to Mandarin Chinese blends. Given the nature of the language and that of their underlying forms, these blends manifest few constraints in formal or categorial terms, contrary to the situation in Russian. The fact that they are usually dissyllabic, however, corresponds to the minimal Prosodic Word of Mandarin, which is a sign of conventionalization. This leads to the conclusion that what blends in the two languages have in common is the role of the minimal Prosodic Word.

Finally, Elke Ronneberger-Sibold proffers a contrastive analysis of lexical blending in German, Farsi and Mandarin Chinese and makes use of an original typology of blends based on relative degrees of transparency of the output (from the point of view of the producer). She shows that while the telescope blends found in German (e.g. Kamelefant $<$ Kamel + Elefant) are absent in both Farsi and Mandarin, contour blends (e.g. German Tomoffel $<$ Tomate + Kartoffel) occur in all three languages, which she explains by the fact the latter are based on a universal ability to identify words by their abstract sound shapes (i.e. mainly their rhythmical contour and the vowel which carries main stress).

The last five contributions provide a theoretically original focus on English and Spanish data. First, Stefan Th. Gries discusses a variety of case studies concerned with the effects of similarity and recognizability on the formation of blends, focusing on the degree of similarity between the two source words that are blended, the ordering of source words in blends and the ways in which source words are split up and merged into blends. His contribution draws comparisons between speech-error blends (both authentic and induced) and intentional word-formation blends, as well as between the latter and complex clippings, and extends previous work by proposing new corpus-linguistic operationalizations of relevant concepts and increasing the sample sizes from previous studies in the field. Some of the variables that are quantified are the length, frequency, stress pattern, semantics, ordering and locus of similarity of source words, as well as the overall similarity of source words to each other and to the resulting blend. 
In Chapter 9, Christian Bassac, a formal linguist, accounts for the form of blends, applying three combinators from Combinatory logic. Interestingly, his operations are on letters, but phonemes would be dealt with in the same way. He then shows how the representations of lexical units in the Generative lexicon can be combined to produce the meanings of blends in a way similar to an earlier treatment of compounds.

In Stress in English blends: a constraint-based analysis, Outi Bat-El and Evan-Gary Cohen study the constraints that govern stress placement in English blends. Starting from the observation that the stressed syllable of the blend is generally identical to that of one of the source words, they attempt to identify factors that determine which of the source words provides its stressed syllable and arrive at a theory that combines the position-based view (which argues that the stress provider is the right-hand source word) and the size-based view (which argues that it is the source word whose size is identical to that of the blend). Their corpus consists of English blends originating from two source words, which involve truncation in at least one of the source words and where truncation is located in the middle of the blend, thus excluding clipped compounds such as sitcom $(<$ situation + comedy). The authors conclude that both size and position play a role in determining stress placement in blends.

Lexical blends have often been considered as products of word creation, rather than word formation, on account of their unpredictability. To overcome the lack of usefulness of rigid rules, Ewa Tomaszewicz applies Optimality-theoretic methods, in particular those of Output to Output Correspondence Theory, which was initially developed to account for resemblances between morphologically related words. Her investigations show that it is less the segments than the prosodic structures that determine which parts of the source words are preserved in the blend.

In the final contribution to the volume, Jochen Trommer and Eva Zimmermann present an Optimality-theoretic account of a specific type of Spanish portmanteau, where the shorter source word is inserted into the prosodic structure of the longer one, which also happens to be the head of the blend (e.g. dedo + democracia $>$ dedocracia). Contra Piñeros (2004), they claim that this type of blend is not created extra-grammatically, but can be derived in the regular morphological component of the grammar. The authors regard this type of portmanteau as a case of templatic shortening aimed at matching a prosodic template.

\section{References}

Algeo, John 
1977 Blends, a structural and systemic view. American Speech 52 (1): 47-64.

Ayto, John

2003 Newspapers and neologisms. In New Media Language, Jean Aitchison and Diana M. Lewis (eds.), 182-186. London: Routledge.

Bat-El, Outi

1996 Selecting the best of the worst: The grammar of Hebrew blends. Phonology 13 (3): 283-328.

Bat-El, Outi

2006 Blends. In Encyclopedia of Language and Linguistics, 2d ed, Vol. 2, Keith Brown (ed.-in-chief), 66-70. Amsterdam: Elsevier.

Bauer, Laurie

2004 A Glossary of Morphology. Edinburgh: Edinburgh University Press.

Berman, Ruth A.

1989 The role of blends in Modern Hebrew word-formation. In Studia Linguistica et Orientalia Memoriae Haim Blanc Dedicata, Paul Wexler, Alexander Borg, and Sasson Somekh

Bertinetto, Pier Marco (eds.), 45-61. Wiesbaden: Harrassowitz.

2001 Blends and syllabic structure: A four-fold comparison. In $\mathrm{La}$ Gramàtica i la Semàntica en l'Estudi de la Variació, Mercè Lorente, Núria Alturo, Emili Boix, Maria-Rosa Lloret, and LLuís Payrató (eds.), 59-112. Barcelona: Promociones y Publicaciones Universitarias / Secció de Lingüística Catalana de la Universitat de Barcelona.

Brdar-Szabó, Rita, and Mario Brdar

2008 On the marginality of lexical blending. Jezikoslovlje $9(1 / 2)$ : 171-194.

Cannon, Garland

1986 Blends in English word formation. Linguistics 24 (4): $725-$ 753.

Cannon, Garland

2000 Blending. In Morphology: An International Handbook on Inflection and Word-Formation, Vol. 1, Geert E. Booij, Christian Lehmann, and Joachim Mugdan (eds.), 952-956. Berlin/New York: Walter de Gruyter.

Cook, Paul, and Suzanne Stevenson

2010 Automatically identifying the source words of lexical blends in English. Computational Linguistics 36 (1): 129-149.

Cutler, E. Anne, and Duncan Young 
1994 Rhythmic structure of word blends in English. In ICSLP 94: 1994 International Conference on Spoken Language Processing: September 18-22, 1994, Yokohama, Japan, Vol. 3, 14071410. Kobe: Acoustical Society of Japan.

Dardjowidjojo, Soenjono

1979 Acronymic Patterns in Indonesian. Pacific Linguistics Series C 45: $143-160$.

Dressler, Wolfgang U.

2000 Extragrammatical vs. marginal morphology. In Extragrammatical and Marginal Morphology, Ursula Doleschal and Anna M. Thornton (eds.), 1-10. Munich: Lincom Europa.

Fradin, Bernard, Fabio Montermini, and Marc Plénat

2009 Morphologie grammaticale et extragrammaticale. In Aperçus de Morphologie du Français, Bernard Fradin, Françoise Kerleroux, and Marc Plénat (eds.), 21-45. Saint-Denis: Presses Universitaires de Vincennes.

Gries, Stefan Th.

2006 Cognitive determinants of subtractive word formation: A corpus-based perspective. Cognitive Linguistics 17 (4): 535-558.

Hong, Sung-Hoon

2005 An optimality theoretic analysis of English blends. Korean Journal of Linguistics 30 (3): 525-557.

Kelly, Michael H.

1998 To "brunch" or to "brench": Some aspects of blend structure. Linguistics 36 (3): 579-590.

Kemmer, Suzanne

2003 Schemas and lexical blends. In Motivation in Language: Studies in Honor of Günter Radden, Hubert Cuyckens, Thomas Berg, René Dirven, and Klaus-Uwe Panther (eds.), 69-97. Amsterdam/Philadelphia: Benjamins.

Kubozono, Haruo

1990 Phonological constraints on blending in English as a case for phonology-morphology interface. Yearbook of Morphology 3: $1-20$

Lehrer, Adrienne

1996 Identifying and interpreting blends: An experimental approach. Cognitive Linguistics. 7 (4): 359-390.

Lehrer, Adrienne

2003 Understanding trendy neologisms. Rivista di Linguistica 15 (2): 369-382.

Lehrer, Adrienne 
2007 Blendalicious. In Lexical Creativity, Texts, and Contexts, Judith Munat (ed.), 115-133. Amsterdam/Philadelphia: Benjamins.

López Rúa, Paula

2004 The categorial continuum of English blends. English Studies 85 (1): 63-76.

Piñeros, Carlos-Eduardo

2004 The creation of portmanteaus in the extragrammatical morphology of Spanish. Probus 16 (2): 203-240.

Plag, Ingo

2003 Word-Formation in English. Cambridge: Cambridge University Press.

Renner, Vincent, and Gordana Lalić-Krstin

2011 Predicting stress assignment in lexical blends: the case of English and Serbian. In ELLSIIR Proceedings, Vol. 1, Nenad Tomović and Jelena Vujić (eds.), 265-273. Belgrade: Publications of the Faculty of Philology of the University of Belgrade.

Veale, Tony, and Cristina Butnariu

2010 Harvesting and understanding on-line neologisms. In Cognitive Perspectives on Word Formation, Alexander Onysko and Sascha Michel (eds.), 399-420. Berlin/New York: De Gruyter Mouton. 